\title{
Blood profile of growing dromedary camel fed varying levels of dried Gawo (Faidherbia albida) leaves in the Northern Guinea Savannah of Nigeria
}

\author{
Ibrahim, H. ${ }^{1 *}$, Lamidi O. S. ${ }^{1}$, Hassan M. R. ${ }^{2}$, Abdullahi M. ${ }^{1}$, Zakariya, M. W. ${ }^{1}$ and Ahmed, S. \\ ${ }^{1}$ National Animal Production Research Institute, Shika-Zaria, Nigeria. \\ ${ }^{2}$ Department of Animal Science, Faculty of Agriculture, Ahmadu Bello University, Zaria, Nigeria. \\ *Corresponding author. Email: elharunibrahim@gmail.com. Tel: 08034652975.
}

Copyright (@) 2017 Ibrahim et al. This article remains permanently open access under the terms of the Creative Commons Attribution License 4.0, which permits unrestricted use, distribution, and reproduction in any medium, provided the original work is properly cited.

Received 17th October, 2017; Accepted 9th November, 2017

\begin{abstract}
This study was carried out to evaluate the effect of dried Faidherbia albida leaves on some haematological and biochemical parameters of growing dromedary camels. Four male camels weighing on average $228.51 \mathrm{~kg}$ were randomly allocated to 4 diets containing $0,10,20$ and 30\% dried F. Albida leaves in a $4 \times 4$ Latin Square Design. Normal haematological (whites blood cells, Red blood cells, Packed cells volume and haemoglobin concentration), different Leucocytes count (Neutrophils, Esinophils, Lymphocytes, Monocytes, Basophils) and Serum biochemical parameters have been determined. Statistical analysis showed there were significant differences in all the parameters. However, the values were within the normal reference values. Hence, dried $F$. albida leaves can be included in the diets of camels up to $30 \%$ without detrimental effect on their blood profile in the northern guinea savannah of Nigeria.
\end{abstract}

Key words: Blood profile, browse plant, camel.

\section{INTRODUCTION}

There has been a trend of growing numbers of camels in the world between 2001 and 2011 (FAO, 2013). This increase might be attributed to changing of environment from the savannah to arid and semi-arid condition, development in camel farming, and an improved ecological image of camel farming and products. The total camelids population in the world in 2013 was estimated at around 25 million animals. This number is probably underestimated because camels are migrant animals. It is difficult to conduct a census for camels such as the wild Australian camel population. The general estimate of the camel world population may probably be around 30 million head (Faye, 2013). About $88 \%$ of the camels are found in Africa, while Asia has $12 \%$. The main concentration of dromedary camels in Africa is in the East African countries with $80 \%$ of the total camel population raised under various production systems.

The most important countries with a camel population of more than 1 million are Somalia, Sudan, Ethiopia, Niger, Mauritania, Chad, and Kenya. A significant proportion $(71 \%$ of total world camels) of the world camel population is found in countries defined by FAO as Net Food Importing Developing Countries, Low Income Food Deficit Countries hold $68 \%$ of total world camels and Least Developed Countries had 59\% of total world camels (Kadim et al., 2014). Nigeria in particular has about 28,000 camels (NASS, 2011) which are concentrated in the Sahelian region of the North western part of Nigeria (FDCPLS, 1992).

Camels (Camelus dromedarius) are reared by nomadic pastoralists mostly in marginal eco-zones of semi-desert lands in sub-Saharan areas. Thus, camels have a vital role in the subsistence economy of large sectors of rural pastoral communities (Abbas and Omer, 2005). Several studies have shown that camels are good source of milk and they constitute the most important source of meat in arid areas (Farah et al., 1992). Mostly camels are raised under true nomadic husbandry systems, therefore, camel pastoralists are always moving over large areas in search of food and water for their camels. During their continuous transhumance, camels are affected by many production-limiting factors such as diseases, range and 
Table1. Ingredients Composition of the experimental diets fed to dromedary camels.

\begin{tabular}{|c|c|c|c|c|}
\hline \multirow{2}{*}{$\begin{array}{l}\text { Ingredients (\%) } \\
\text { F. albida leaves }\end{array}$} & \multicolumn{4}{|c|}{ Inclusion levels of dried $F$. albida dry leaves (\%) } \\
\hline & 0 & 10 & 20 & 30 \\
\hline Maize offals & 43.86 & 39.20 & 35.07 & 30.63 \\
\hline Wheat offals & 43.86 & 39.20 & 35.07 & 30.63 \\
\hline Cotton seed cake & 5.53 & 4.86 & 3.11 & 2.00 \\
\hline Bone meal & 5 & 5 & 5 & 5 \\
\hline Salt & 0.25 & 0.25 & 0.25 & 0.25 \\
\hline Premix & 1.5 & 1.5 & 1.5 & 1.5 \\
\hline Total & 100.00 & 100.00 & 100.00 & 100.00 \\
\hline \multicolumn{5}{|c|}{ Calculated analysis } \\
\hline Crude protein & 14.31 & 14.43 & 14.34 & 14.41 \\
\hline ME: kcal/kg & 1912 & 2028 & 2135 & 2214 \\
\hline Crude fiber & 16.69 & 14.91 & 15.89 & 14.88 \\
\hline Ether extract & 3.32 & 2.98 & 3.22 & 2.08 \\
\hline Ca: $P$ ratio & 1.8 & 1.8 & 1.8 & 1.8 \\
\hline Met+ cysteine & 0.38 & 0.43 & 0.46 & 0.46 \\
\hline
\end{tabular}

pasture limitations, water scarcity, high calf mortality and, recently, security problems (Abbas and Omer, 2005, Ali and Majid, 2006).

Raising edible animals with low-price meat such as camels is one way of bridging the gap between the demand for meat and the poor purchasing power in the less developed countries (FAO, 1995). The methods of camel keeping are now fast changing due to the shrinkage of natural grazing land as a result of the establishment of mechanized irrigated or rain-fed agricultural schemes in parts of the natural camel range lands as well as the very severe and historical drought that hit several camel producing countries (Omer et al., 2016). These natural disasters had aggravated the situation and forced many camel herders to start settling since these periods (Abbas and Omer, 2005, Darosa, 2005). Moreover, in order to keep pace with the alarming nutritional crisis, to make the ration economic and to have sustainable camel rearing practice, attempts were made to formulate least cost balanced rations for camels using the most preferred browse plant.

Due to the introduction of these new feed resources, it is justified to study the effect of some of these new diets on the normal blood and biochemical parameters of camels. This study is an attempt to investigate the effect of Faidherbia albida leaves on some haematological and biochemical parameters of growing dromedary camel in the Northern Guinea Savannah of Nigeria.

\section{MATERIALS AND METHODS}

\section{Study area}

This study was carried out at the Equine and camel research programme, National Animal Production Research Institute, Ahmadu Bello University, Shika-Zaria, Nigeria on latitude $11^{0} 12^{\circ} \mathrm{N}$, longitude $7^{0} 33^{\circ} \mathrm{E}$ and on altitude of $610 \mathrm{~m}$ above sea level (Ovimaps, 2015).

\section{Management of animals and experimental design}

Four (4) growing male camels with an average body weight of $228.51 \mathrm{~kg}$ were purchased from Mai'adua market in Katsina state and used for the study. The animals were dewormed orally with Sambezole suspension, sprayed with Amitrix against internal and external parasites, respectively. The animals were placed in a separate pen equipped with water and feeding trough. Animals were then randomly allocated to 4 diets containing $0,10,20$ and $30 \%$ dried $F$. albida leaves in a 4 $x 4$ Latin Square Design. The animals were fed the experimental diets at $3 \%$ of their body weight on daily basis as recommended by (Mohamed, 2007). The experiment comprised of four periods and each period lasted for 65 days. Blood samples were collected from each animal at the end of each period.

\section{Experimental diets}

Four (4) dietary treatments (Table 1) containing maize offal, wheat offal, cotton seed cake, bone meal, salt and premix at varying inclusion levels $(0 \%, 10 \%, 20 \%$ and $30 \%$ ) of dried Faidherbia albida leaves were formulated and used for the experiment.

\section{Laboratory analysis}

Experimental diets were subjected to proximate analysis 
Table 2. Chemical composition of experimental diets and F. albida leaves

\begin{tabular}{lccccc}
\hline \multirow{2}{*}{ Parameters } & \multicolumn{4}{c}{ Inclusion levels of dried $\boldsymbol{F}$. albida dry leaves $\mathbf{( \% )}$} & \multirow{2}{*}{ F. albida leaves } \\
\cline { 2 - 5 } & $\mathbf{0}$ & $\mathbf{1 0}$ & $\mathbf{2 0}$ & $\mathbf{3 0}$ & \\
\hline Dry matter & 90.82 & 91.16 & 91.23 & 91.81 & 90.89 \\
Crude protein & 15.63 & 15.75 & 16.19 & 14.69 & 15.81 \\
Crude fiber & 28.16 & 29.67 & 26.98 & 26.86 & 21.57 \\
Ether extract & 12.63 & 12.03 & 12.04 & 10.52 & 9.91 \\
Ash & 8.55 & 9.14 & 8.73 & 11.06 & 7.84 \\
ADF & 24.58 & 31.59 & 35.44 & 36.64 & 59.89 \\
NDF & 44.92 & 50.29 & 47.83 & 50.20 & 66.51 \\
NFE & 25.85 & 24.57 & 27.29 & 28.68 & 35.76 \\
\hline
\end{tabular}

ADF, Acid detergent fiber, NDF, Neutral detergent fiber, NFE, Nitrogen free extract.

Table 3. Effect of varying levels of dried Faidherbia albida leaves on blood haematology of dromedary camels.

\begin{tabular}{lcccccc}
\hline \multirow{2}{*}{ Parameters } & \multicolumn{9}{c}{ Inclusion levels dried $\boldsymbol{F}$. albida leaves $(\%)$} & \multirow{2}{*}{ SEM } & \multirow{2}{*}{ Ref. Val. } \\
\cline { 2 - 5 } & $\mathbf{0}$ & $\mathbf{1 0}$ & $\mathbf{2 0}$ & $\mathbf{3 0}$ & & \\
\hline WBC $\left(\times 10^{9} / \mathrm{L}\right)$ & $13.01^{\mathrm{c}}$ & $9.21^{\mathrm{d}}$ & $14.41^{\mathrm{b}}$ & $19.19^{\mathrm{a}}$ & 0.39 & $12.1-25.3$ \\
RBC $\left(\times 10^{9} / \mathrm{L}\right)$ & $7.92^{\mathrm{a}}$ & $6.53^{\mathrm{c}}$ & $6.98^{\mathrm{b}}$ & $7.79^{\mathrm{a}}$ & 0.14 & $5.1-9.1$ \\
PCV $(\%)$ & $30.32^{\mathrm{b}}$ & $27.73^{\mathrm{d}}$ & $28.87^{\mathrm{c}}$ & $31.79^{\mathrm{a}}$ & 0.11 & $25-32.1$ \\
Hb Conc. $(\mathrm{g} / \mathrm{dl})$ & $10.78^{\mathrm{b}}$ & $10.66^{\mathrm{b}}$ & $11.43^{\mathrm{a}}$ & $10.89^{\mathrm{ab}}$ & 0.28 & $9.2-14.1$ \\
\hline
\end{tabular}

WBC, White blood cells, RBC, Red blood cells, PCV, Packed cells volume, Hb Conc., Haemoglobin concentration, SEM, Standard error of mean, Ref. Val., Reference Value.

(Table 2) according to the method of AOAC (2004). The Nitrogen Free Extract (NFE) was calculated as NFE\% = $\{\mathrm{DM}-(\mathrm{EE} \%+\mathrm{CP} \%+\mathrm{CF} \%+\mathrm{ASH} \%)$. Neutral Detergent Fiber (NDF) and Acid Detergent Fiber (ADF) were determined according to Goering and Van Soest (1970). Dried $F$. albida leaves were also analyzed for tannin, saponin and alkanoid at Food Science Laboratory, Institute of Agricultural Research, Samaru, Nigeria.

\section{Blood sample collection and evaluation}

Evaluation of blood samples was carried out at the Ahmadu Bello University Teaching Hospital. Ten (10) ml of blood samples were collected from the jugular vein of each camel at the end of each period, with the use of 10 $\mathrm{ml}$ plastic disposable syringes and placed into two separate sets of Vacutainer tubes; in which $7 \mathrm{ml}$ was placed into EDTA (Ethylene Diamine Tetra Acetic Acid) bottle while the remaining $3 \mathrm{ml}$ was placed into plain bottle. The anti-coagulated blood was used immediately for the determination of Erythrocyte count, Packed Cell Volume (PCV), Hemoglobin ( $\mathrm{Hb}$ ) concentration and Total Leukocyte count as described by Ewuola and Egbunike (2008). The plain blood sample was allowed to clot by leaving it undisturbed at room temperature for 30 minutes. Clotted blood was removed by centrifuging at 1,000 to $2,000 \times \mathrm{g}$ for 10 minutes in a refrigerated centrifuge as described by Thavasu (1992). The serum was analyzed spectrophotometrically for sodium, potassium, urea, creatinine, total protein and albumin as described by Mohammed et al. (2007). Globulin was calculated by subtracting the concentration of albumin from the concentration of total protein as described by Coles (1974) and reported by Mohammed et al. (2007). Blood glucose level was determined by Coles (1974) method, using appropriate test kits.

\section{Data analysis}

The data collected on haematological parameters, different leucocytes count and serum biochemical parameters were subjected to Analysis of Variance Procedure of Steel and Torrie (1980). Significant differences between means were separated using Dunette's Test (Dunette, 1955).

\section{RESULTS}

\section{Haematological parameters}

The results of haematology and different leucocytes count of the camels fed diets containing varying levels of dried Faidherbia albida leaves are presented in Table 3 
and 4. The white (Total leucocytes count) and red (Total erythrocytes count) blood cells were higher in camels on diet containing $30 \%$ dried $F$. albida leaves $\left(19.19 \times 10^{9} / \mathrm{L}\right.$ and $7.92 \times 10 \%$ L respectively) in which the packed cell volumes ranged from 27.73 to $31.79 \%$. However, the haemoglobin concentration ranged from $10.66 \mathrm{~g} / \mathrm{dl}$ to $11.43 \mathrm{~g} / \mathrm{dl}$ and higher $(11.43 \mathrm{~g} / \mathrm{dl})$ value was recorded in camels on diet containing $20 \%$ dried $F$. albida leaves.

\section{Different Leucocytes count (White blood cells)}

Camels on $30 \%$ dried $F$. albida leaves obtained the highest $(30.37 \%$ and $5.84 \%)$ percent neutrophils and esinophils respectively. Percent lymphocyte in the blood ranged from 42.19 to $50.49 \%$ whereas percentage monocytes and basophils ranged from 3.90 to $6.38 \%$ and 0.40 to $0.58 \%$ respectively. However, higher lymphocytes $(50.49 \%)$, monocytes $(6.38 \%)$ and basophils $(0.58 \%)$ were observed in camels on diet 10,30 and $0 \%$ dried $F$. albida leaves respectively.

\section{Serum biochemical parameters}

The results of serum biochemical parameters of camels fed varying levels of dried Faidherbia albida leaves were presented in Table 5 . The total protein and albumin content recorded in this study ranged from 8.45 to $9.63 \mathrm{~g} / \mathrm{dl}$ and 2.95 to $5.04 \mathrm{~g} / \mathrm{dl}$ respectively. However, animal on diet containing $20 \%$ dried $F$. albida leaves had the highest total protein $(9.63 \mathrm{~g} / \mathrm{dl})$ and albumin $(5.04$ $\mathrm{g} / \mathrm{dl}$ ) content while those on control diet had the least $(8.45 \mathrm{~g} / \mathrm{dl}$ and $2.95 \mathrm{~g} / \mathrm{dl}$ respectively). Globulin concentration ranged from $4.59 \mathrm{mg} / \mathrm{dl}$ to $5.50 \mathrm{mg} / \mathrm{dl}$ and higher $(36.06 \mathrm{mg} / \mathrm{dl})$ glucose level was obtained in camels on control diet. However, the creatinine and triglyceride levels ranged from 0.95 to $1.21 \mathrm{mg} / \mathrm{dl}$ and 27.40 to $30.35 \mathrm{mg} / \mathrm{dl}$ respectively with camels on diet containing $20 \%$ and $30 \%$ dried $F$. albida leaves having the highest creatinine $(1.21 \mathrm{mg} / \mathrm{dl})$ and triglyceride $(30.35$ $\mathrm{mg} / \mathrm{dl}$ ), respectively. Higher $(44.72 \mathrm{mg} / \mathrm{dl})$ blood urea concentration was recorded in animals on diet containing $20 \%$ dried $F$. albida leaves.

Camels on diets containing 0 and $20 \%$ dried Faidherbia albida leaves recorded a statistically similar sodium level in the blood. However, the potassium and calcium levels ranged from 2.10 to $2.55 \mathrm{mEq} / \mathrm{l}$ and 7.80 to $9.17 \mathrm{mg} / \mathrm{l}$ respectively.

\section{DISCUSSION}

\section{Effect of diets containing varying levels of dried Faidherbia albida leaves on blood haematology of growing dromedary camels}

Table 3 showed the effect of varying levels of dried $F$. albida leaves on haematological parameters of dromedary camels. The white blood cells (WBC) ranged $13.01 \times 10 \% / \mathrm{L}$ to $19.19 \times 10^{9} / \mathrm{L}$ with camels on diet containing $30 \%$ level of dried $F$. albida leaves having a significantly $(p<0.05)$ higher $\left(19.19 \times 10^{9} / L\right)$ WBC when compared with those on the other diets. The values of WBC obtained in this study are comparable with values $\left(11.97 \times 10^{9} / \mathrm{L}\right.$ and $11.54 \mathrm{x}$ $\left.10 \times 10^{9} / \mathrm{L}\right)$ reported by Ahmad et al. (2004) and Alsaad (2009) respectively. The values recorded in this study were within the ranged $\left(12.1\right.$ to $\left.25.3 \times 10^{9} / \mathrm{L}\right)$ reported by AL-Busadah and Abdel-Gadir (2004). The values of red blood cells (RBC) and packed cell volume (PCV) recorded in this study ranged from $6.53 \times 10 \% / \mathrm{L}$ to $7.92 \times 10 \%$ L and 27.73 to $31.79 \%$ respectively. However, there were significant $(p<0.05)$ differences in RBC and PCV of the camels across the diets. Camels on diets containing 0 and $30 \%$ levels of dried $F$. albida leaves had a statistically similar values of RBC in the blood while camels on $30 \%$ level of dried $F$. albida leaves recorded the highest $(p<0.05)$ PCV as compared to those on the other diets. The values for RBC obtained in this study are in line with the findings of Ahmad et al. (2004) who reported mean red blood cells of $6.93 \times 10^{9} / \mathrm{L}$. Relatively similar values of $7.40 \times 10 \% / \mathrm{L}$ and $7.92 \times 10^{9} / \mathrm{L}$ of $\mathrm{RBC}$ have been reported by Al-Sultan (2008) and Alsaad (2009) respectively. Hence, the variation in red blood cells of the camels in this study may be associated with the levels of dried $F$. albida leaves and or health status of the animals (Al-Sultan, 2008). However, the RBC values were within the ranged reported by AL-Busadah and Abdel-Gadir (2004). The increase in PCV of camels on diet 10,20 and $30 \%$ were attributed to the increase in dried $F$. albida leaves in the diets. The PCV values recorded in the present study were also within the ranged provided by Osman and Al-Busadah (2003). The values of haemoglobin concentrations obtained in the present study ranged from 10.66 to $11.43 \mathrm{~g} / \mathrm{dl}$ with camels on diets containing 20 and $30 \%$ levels of dried $F$. albida leaves having a significantly higher $(11.38 \mathrm{~g} / \mathrm{dl}$ and $10.89 \mathrm{~g} / \mathrm{dl}$ ) haemoglobin concentration as compared to those on the other diets. The values for haemoglobin concentration of the camels across the diets were within the ranged (9.2 to $14.4 \mathrm{~g} / \mathrm{dl}$ ) reported by Farooq et al. (2011).

\section{Effect of diets containing varying levels of dried Faidherbia albida leaves on different leucocytes count of growing dromedary camels}

Table 4 showed the effect of varying levels of $F$. albida leaves on different leucocytes count of growing dromedary camels. The percentage neutrophils obtained in this study ranged from 23.33 to $30.79 \%$. However, there were significant $(\mathrm{P}<0.05)$ differences in percentage neutrophils of the camels across the diets with animals on diet containing $30 \%$ dried F. albida leaves having a significantly $(\mathrm{P}<0.05)$ higher percent neutrophils when compared with the values obtained in the other camels. 
Table 4. Effect of varying levels of dried Faidherbia albida leaves on Different Leucocytes count (White blood cells) of growing dromedary camels.

\begin{tabular}{|c|c|c|c|c|c|c|}
\hline \multirow{2}{*}{ Parameters } & \multicolumn{4}{|c|}{ Inclusion levels of dried $F$. albida leaves (\%) } & \multirow{2}{*}{ SEM } & \multirow{2}{*}{ Normal range } \\
\hline & 0 & 10 & 20 & 30 & & \\
\hline Neutrophils (\%) & $29.51^{\mathrm{b}}$ & $23.23^{d}$ & $27.67^{c}$ & $30.79^{a}$ & 0.52 & $22-48$ \\
\hline Esinophils (\%) & $4.95^{\mathrm{b}}$ & $4.35^{\mathrm{c}}$ & $4.57^{\mathrm{c}}$ & $5.84^{\mathrm{a}}$ & 0.13 & $3.5-6.0$ \\
\hline Lymphocytes (\%) & $44.56^{c}$ & $50.49^{a}$ & $49.28^{b}$ & $42.19^{d}$ & 0.52 & $41.2-56.4$ \\
\hline Monocytes (\%) & $5.20^{\mathrm{b}}$ & $4.48^{\mathrm{c}}$ & $3.90^{\mathrm{d}}$ & $6.38^{a}$ & 0.24 & $3-8$ \\
\hline Basophils (\%) & $0.58^{\mathrm{a}}$ & $0.46^{b}$ & $0.40^{\mathrm{b}}$ & $0.45^{b}$ & 0.04 & $0.00-2.1$ \\
\hline
\end{tabular}

SEM, Standard error of mean.

Table 5. Effect of varying levels of dried $F$. albida leaves on serum protein profile of growing dromedary camels.

\begin{tabular}{lcccccc}
\hline \multirow{2}{*}{ Parameters } & \multicolumn{9}{c}{ Inclusion levels of dried $\boldsymbol{F}$. albida leaves $(\%)$} & \multirow{2}{*}{ SEM } & \multirow{2}{*}{ Ref. Val. } \\
\cline { 2 - 5 } & $\mathbf{0}$ & $\mathbf{1 0}$ & $\mathbf{2 0}$ & $\mathbf{3 0}$ & & \\
\hline Total protein $(\mathrm{g} / \mathrm{dl})$ & $8.45^{\mathrm{b}}$ & $8.84^{\mathrm{b}}$ & $9.63^{\mathrm{a}}$ & $8.67^{\mathrm{b}}$ & 0.29 & $4.9-10.2$ \\
Albumin $(\mathrm{g} / \mathrm{d} \mathrm{l})$ & $2.95^{\mathrm{c}}$ & $3.55^{\mathrm{b}}$ & $5.04^{\mathrm{a}}$ & $3.48^{\mathrm{b}}$ & 0.14 & $1.78-6.2$ \\
Globulin $(\mathrm{mg} / \mathrm{dl})$ & $5.50^{\mathrm{a}}$ & $5.29^{\mathrm{b}}$ & $4.59^{\mathrm{c}}$ & $5.19^{\mathrm{b}}$ & 0.07 & $1.5-5.4$ \\
Glucose $(\mathrm{mg} / \mathrm{dl})$ & $36.06^{\mathrm{a}}$ & $33.55^{\mathrm{bc}}$ & $35.69^{\mathrm{ab}}$ & $33.20^{\mathrm{c}}$ & 1.07 & $33.66-118.70$ \\
Creatinine $(\mathrm{mg} / \mathrm{dl})$ & $0.95^{\mathrm{b}}$ & $1.04^{\mathrm{ab}}$ & $1.21^{\mathrm{a}}$ & $0.99^{\mathrm{a}}$ & 0.11 & $0.96-1.45$ \\
Triglycerides $(\mathrm{mg} / \mathrm{dl})$ & 27.40 & 27.58 & 28.81 & 30.35 & 1.55 & $28-45$ \\
Urea $(\mathrm{mg} / \mathrm{dl})$ & 39.50 & 38.78 & 41.72 & 42.56 & 4.20 & $15-45$ \\
\hline
\end{tabular}

SEM, Standard error of mean, a,b,c, Means in the same row with different superscript are significantly different, Ref. Va., Reference Value.

However, this may be attributed to the high levels of dried $F$. albida leaves in the diet. The values of percentage neutrophils obtained in this study were within the range (22 to $48 \%$ ) reported by Bogin (2000) in his study on camelids.

The percentage esinophils and lymphocytes obtained in this study ranged from 4.35 to $5.84 \%$ and 42.19 to $50.49 \%$ respectively. There were significant $(p<0.05)$ differences in percentage esinophils and lymphocytes of the camels across the diets with camels on diet containing 30 and $10 \%$ having a significantly $(p<0.05)$ higher percentage esinophils (5.84\%) and lymphocytes $(50.49 \%)$ respectively. However, the percentage esinophils obtained in the present study were similar to the mean values $(4.42 \%, 3.92 \%$ and $4.97 \%)$ of esinophils documented by Aichouni et al. (2010). The values obtained for percentage esinophils in this study were within the ranged (3.5 to 6.0\%) reported by Bogin (2000). Mohammed (2012) in his study on some haematologic values and serum biochemical parameters of dromedary camels reported percentage lymphocytes of $40.00,45.00$, 50.00 and $54.00 \%$. The variation in percentage lymphocytes may be associated with the levels of dried $F$. albida leaves. The percentage monocytes and basophiles recorded in this study ranged from 3.90 to $6.38 \%$ and 0.40 to $0.58 \%$ respectively. There were significant $(p<0.05)$ differences in both percentage monocytes and basophiles across the diets with animals on diets containing 30 and $0 \%$ levels of dried $F$. Albida leaves having the highest $(p<0.05)(6.38$ and $0.58 \%)$ percentage monocytes and basophiles respectively. Differences in percentage basophils may be attributed to differences in diets and or levels of dried F. albida leaves in the diets.

\section{Effect of diets containing varying levels of dried Faidherbia albida leaves on serum protein profile of growing dromedary camels}

Results concerning the effect of varying levels of dried $F$. albida leave on blood metabolites of camels are presented in Table 5 . There were significant $(p<0.05)$ differences in total proteins and albumin content of the camels across the diets with camels on diet containing 10 and $20 \%$ levels of dried $F$. albida leaves having the higher total protein $(8.84$ and $9.63 \mathrm{~g} / \mathrm{dl})$ and albumin $(3.55$ and $5.04 \mathrm{~g} / \mathrm{dl}$ ) levels in the blood. Adel and El-Metwaly (2012) reported a total protein of $9.21,9.35$ and $9.01 \mathrm{~g} / \mathrm{dl}$ which were almost similar to the values obtained in this study. However, the values for total protein obtained in this study were within the ranged (4.9 to $10.2 \mathrm{~g} / \mathrm{dl}$ ) reported by Osman and Al-Busadah (2003) and Farooq et al. (2011). The higher level of total protein of the camels in the present study may be attributed to levels of 
Table 6. Serum macro minerals levels in growing dromedary camels fed diets containing varying levels of dried Faidherbia albida leaves.

\begin{tabular}{lcccccc}
\hline \multirow{2}{*}{ Parameters } & \multicolumn{9}{c}{ Inclusion levels of dried $\boldsymbol{F}$. albida leaves (\%) } & \multirow{2}{*}{ SEM } & \multirow{2}{*}{ Normal range } \\
\cline { 2 - 6 } & $\mathbf{0}$ & $\mathbf{1 0}$ & $\mathbf{2 0}$ & $\mathbf{3 0}$ & & \\
\hline $\mathrm{Na}(\mathrm{mEq} / \mathrm{l})$ & $113.59^{\mathrm{a}}$ & $105.98^{\mathrm{bc}}$ & $110.48^{\mathrm{ab}}$ & $105.28^{\mathrm{c}}$ & 2.47 & $100-190$ \\
$\mathrm{~K}(\mathrm{mEq} / \mathrm{l})$ & $2.55^{\mathrm{a}}$ & $2.15^{\mathrm{b}}$ & $2.10^{\mathrm{b}}$ & $2.20^{\mathrm{b}}$ & 0.16 & $2.9-6.2$ \\
$\mathrm{Ca}(\mathrm{mg} / \mathrm{l})$ & $8.07^{\mathrm{b}}$ & $9.17^{\mathrm{a}}$ & $7.80^{\mathrm{b}}$ & $7.91^{\mathrm{b}}$ & 0.35 & $8.0-10.3$ \\
\hline
\end{tabular}

$\mathbf{N a}$, Sodium, K, Potassium, Ca, Calcium, SEM, Standard error of mean, a,b,c, Means in the same row with different superscript are significantly different.

dried $F$. albida leaves in the diets. However, the values for albumin obtained in this study were within the ranged $(1.78$ to $6.2 \mathrm{mg} / \mathrm{dl})$ reported by Farooq et al. (2011). The globulin levels obtained in this study ranged from 4.59 to $5.50 \mathrm{mg} / \mathrm{dl}$. There were significant $(p<0.05)$ differences in globulin levels in the blood with camels on control diet having the highest $(p<0.05)$ globulin level of $5.50 \mathrm{mg} / \mathrm{dl}$ followed by those on diet containing $20(5.29 \mathrm{mg} / \mathrm{dl})$ and $30 \%(5.19 \mathrm{mg} / \mathrm{dl})$ dried F. albida leaves. The globulin levels of camels on control diet were slightly higher than the ranged (1.5 to $5.4 \mathrm{mg} / \mathrm{dl}$ ) reported by Faroog et al. (2011) while those camels on diet 10, 20 and $30 \%$ dried $F$. albida leaves were within the ranged. There were significant $(p<0.05)$ differences in serum glucose concentration recorded in this study with camels on diet 0 and $20 \%$ levels of dried $F$. albida leaves having a statistically similar (36.06 and $35.69 \mathrm{mg} / \mathrm{dl}$ respectively) blood glucose level. However, the differences in glucose concentration in this study may be associated with the levels of dried $F$. albida leaves in the diet. The creatinine content in the camel's blood ranged from 0.95 to 1.21 $\mathrm{mg} / \mathrm{dl}$. However, there were significant $(\mathrm{p}<0.05)$ differences in creatinine levels in the blood with camels on diet containing $20 \%$ level of dried $F$. albida leaves having a significantly $(p<0.05)$ higher $(1.21 \mathrm{mg} / \mathrm{dl})$ creatinine level. The values of creatinine obtained in this study were similar to the values $(0.97,1.08$ and 1.09 $\mathrm{mg} / \mathrm{dl}$ ) reported by Adel and EL-Metwaly (2012). However, the values obtained in this study were within the ranged reported $(0.96$ to $1.45 \mathrm{mg} / \mathrm{dl})$ by Osman and Al-Busadah (2003). The triglycerides level obtained in this study ranged from 27.40 to $30.35 \mathrm{mg} / \mathrm{dl}$ and there were no significant $(p>0.05)$ differences observed across the diets. The urea concentration in the blood ranged from 38.78 to $42.56 \mathrm{mg} / \mathrm{dl}$. However, there were no significant $(p>0.05)$ differences in urea concentration of the camels blood across the diets. The values for blood urea obtained in this study agree with the report of Eggun (1970) who stated that the blood urea content increased with the protein content in the diet.

Effect of varying levels of dried $F$. albida leaves on serum macro minerals of growing dromedary camels

Table 6 showed the serum macro minerals of growing dromedary camels fed varying levels of $F$. albida leaves. There were significant differences in concentration of macro minerals of the camels across the diets with camels on diets containing 0 and $20 \%$ dried $F$. albida leaves having a significantly $(P<0.05)$ higher sodium concentration as compared to those on the other diets.

The values for potassium and calcium levels in the blood range from 2.15 to $2.55 \mathrm{mEq} / \mathrm{l}$ and 7.91 to 9.17 $\mathrm{mg} / \mathrm{l}$ respectively. Babeker et al. (2013) reported potassium levels of $2.04,2.25,7.19$ and $4.70 \mathrm{mEq} / \mathrm{l}$. However, the potassium levels recorded in the present study were within the ranged (2.9 to $6.2 \mathrm{mEq} / \mathrm{l})$ reported by Bogin (2000). Camels on diet containing $10 \%$ dried $F$. albida leaves had a significantly $(p<0.05)$ higher $(9.17$ $\mathrm{mg} / \mathrm{l})$ calcium level as compare to those on the other diets. The calcium levels reported in this study were within the normal range of 8.0 to $10.3 \mathrm{mg} / \mathrm{dl}$ reported by Osman and Al-Busadah (2003).

\section{Conclusion}

There are few variations between the present results and those from authors which may be associated with the differences nutrition, and or method of analysis. It could be concluded that up to $30 \%$ dried Faidherbia albida leaves in camels feed has no health hazard on the camels as evident from the result of haematology and blood chemistry profiles. It could also be beneficial to provide supplementary feed containing dried Faidherbia leaves to camels kept in the Northern Guinea Savannah of Nigeria.

\section{CONFLICT OF INTEREST}

The authors declare that they have no conflict of interest.

\section{ACKNOWLEDGEMENTS}

The authors acknowledge the help rendered by the Director, National Animal Production Research institute, Ahmadu Bello University, Zaria.

\section{REFERNCES}

Abbas, B., \& Omer, O. H. (2005). Review of infectious diseases 
of the camel. Veterinary Bulletin, 75(8), 1-16.

Adel, E. M., \& EL-Metwaly, H. (2012). Effect of feed additive "Exogenous Enzymes" on growth performance of Maghraby Camels. Life Science Journal, 9(4), 4830-4835.

Ahmad, S., Butt, A. A., Muhammad, G., Athar, M., \& Khan, M. Z. (2004). Haematobiochemical studies on hemoparsitised camels. International Journal of Agricultural Biology, 6(2), 331-334.

Aichouni, A., Jeblawi, R., Dellal, A., Hammou, H., \& Aggad, H. (2010). Breed variation in blood constituents of the onehumped camel (Camelus dromedaries) in Algeria. Journal of Camelid Sciences. 3, 19-25.

AL-Busadah, K. A., \& Abdel-Gadir M. H. (2004). Some Biochemical and Hematological Indices in different breeds of camels in Saudi Arabia. Deanship of Scientific Research King Faisal University. Pakistan Veterinary Journal, 12, 178.182.

Ali, M. S., \& Majid, A. A. (2006). Productive and reproductive characters of camels raised in Butana area in eastern Sudan. Proceedings of the International Scientific Conference on Camels, Qassim, Saudi Arabia. Pp. 2339-2348.

Alsaad, K. M. (2009). Clinical, hematological and biochemical studies of Anaplasmosis in Arabian one-humped camels (Camelus dromedaries). Journal of Animal and Veterinary Advances. 8(11), 2106-2109.

Al-Sultan, S. I. (2008). Studies on hematological and certain biochemical values in young Magaheim dromedary camels at Al-Ahsa province. Veterinary Research. 2(3), 34-37.

Babeker, E. A., Elmansoury, Y. H. A., \& Suleem, A. E. (2013). The influence of seasons on blood constituents of dromedary camel (camelus dromedarius). Online Journal of Animal and Feed Research, 3(1), 01-08.

Bogin, E. (2000). Clinical pathology of Camelides : Present and future. Plenary lecture, Department of Clinical Pathology, Kimron Veterinary Institute, School of Medicine, Beit- Dagan, Israel. Pp. 563-568.

Cole, E. B. (1974). Blood glucose determination. In: Veterinary Clinical Pathology, 2nd edition. Saunders, M.B Company, West Washington Square, Philadelphia: Pp. 272-274.

Darosa, A. E. M. (2005). Studies on Some Camel Production Traits and Health in Butana Area, Sudan. Ph.D. Thesis. University of Khartoum, Sudan. 135.

Dunnett, C. W. (1955). A multiple comparison procedure for comparing several treatments with a control. Journal of American Statistics Association, 50: 1096 - 1121.

Eggum, B. O. (1970). Blood urea measurement as a technique for assessing protein quality. 983-988.

Ewuola, E. O., \& Egbunike, G. N. (2008). Hematological and Serum Biochemical Response of Growing Rabbit Bucks fed Different Levels of Dietary Fumonisin B1. African Journal of Biotechnology, 7, 4304-4309.

FAO (2013). Food and Agriculture Organization of the United Nations Statistics Division. Available at http://faostat3.fao.org/faostat-gateway/go/to/home/E

Accessed 6 August, 2014.
FAO (1995). Quarterly Bulletin of statistics. Food and Agriculture Organization, UN Rome 8, 31-36.

Farah, Z. T. Rellenmayer, R. \& Atkins, D. (1992). Vitamin A content of camel milk. International Journal Vitamin Nut. Res. 62, 30-33.

Farooq, U., Samad, H. A., Khurshid, A., \& Sajjad, S. (2011). Normal reference hematological values of one-humped camels (Camelus dromedarius) kept in Cholistan desert. The Journal of Animal and Plant Sciences, 21(2), 157-160.

Faye, B. (2013). Camel Meat in the World, In. I. T. Kadim, O. Mahgoub, B. Faye and M. M. Farouk. (Eds). Camel Meat and Meat Products CABI International, Wallingford, England, ISBN: 9781780641 010: 7-16.

FDCPLS, (1992). Federal Department of Livestock and Pest Control Services. Nigerian Livestock Resources. Volume III: State Reports. Edited by Resource Inventory and Management Ltd. (RIM).

Kadim I. T., Mahgoub, O. and M. Mbaga†, M. (2014). Potential of camel meat as a non-traditional high quality source of protein for human consumption. Journal of Food Science, 4 (4): 1-13.

Mohamed, M. I. (2007). Evaluation of Growth Performance for Growing Maghraby Camel Fed on Un-conventional Feed. International Journal Agricultural Biology, 9(1)18-21.

Mohammed, A. K., Sackey, A. K., Tekdek, B. L. B. \& Gefu, J. O. (2007). Serum biochemical values of adult one humped camel (Camelus dromedarius) introduced in to a sub-humid climate in Shika-Zaria, Nigeria. Journal of Animal and Veterinary Advances 6(5), 597-600.

Mohammed, S. A. (2012). Some hematologic values and serum biochemical parameters in male camels (Camelus dromedarius) before and during rut. Asian Journal of Animal and Veterinary Advances, 6(11), 567-575.

Osman, T. E. A. \& Al-Busadah, K. A. (2003). Normal concentration of twenty serum biochemical parameters of she-camels, cows and ewes in Saudi Arabia. Pakistan Journal of Biological Sciences, 6(14), 1253-1256.

Ovimaps, (2015). Ovi Location Map; Ovi Earth Imaginary. Retrieved on 16th November, 2015.

Steel, R. G. D. and Torrie, J. H. (1980). Principles and Procedures of Statistics. Second Edition, New York: McGrawHill Book Co. New York.

Thavasu, P. W. (1992). Measuring cytokine levels in blood. Importance of anticoagulants, processing, and storage conditions. Journal of Immunol Methods, 153, 115-124. 